\title{
Some Comparative Immunohistochemical Studies on the Ductus Deferens in the Donkey (Equus asi- nus) and Water Buffalo Bull (Bubalus bubalis).
}

\author{
Mohamed Alkafafy ${ }^{1)}$, Hossam Attia ${ }^{2)}$, Reda Rashed ${ }^{3)}$, Mohamed Kan- \\ diel $^{4)}$ \\ 1) Department of Cytology and Histology, Faculty of Veterinary Medicine, Minoufiya University, \\ Sadat City Branch, Egypt. \\ 2) Department of Histology and Cytology, Faculty of Veterinary Medicine, Benha University, Tok- \\ heh, Kaliobia, Egypt. \\ 3) Department of Anatomy and Embryology, Faculty of veterinary Medicine, Minoufiya University, \\ Sadat City branch, Egypt. \\ 4) Department of Theriogenology, Faculty of Veterinary Medicine, Benha University, Tokheh, Kali- \\ obia, Egypt.
}

With 3 figures

Received February, Accepted for publication March 2010

\section{Abstract}

The current work aimed to apply immunohistochemistry (IHC) to evaluate the differential distribution pattern of some biologically active proteins in the ductus deferens (DD) in two different animal species common in the Egyptian farms. Immunolocalization of S100, angiotensin converting enzyme (ACE), $\alpha$ smooth muscle actin ( $\alpha-S M A)$, connexin 43 (Cx43) and galactosyltransferase (GalTase) was practiced on paraffinembedded sections of DD from clinically healthy adult five donkeys and five water buffalo bulls. The DD, in both species, was lined by a folded, high cuboidal (in donkey) or tall columnar (in buffalo) pseudostratified epithelium with stereocilia. IHC revealed that all antibodies used, displayed variable reactivities in the two species. Nerves and the periductal smooth muscles expressed a strong immunoreactivity (IR) for S100 and $\alpha$-SMA respectively; both in the donkey and in the buffalo. Stereocilia of principal cells showed a marked ACEimmunostaining in the donkey but not in

J. Vet. Anat. the buffalo. Cx43-binding sites were found between the basal portions of the ductal epithelium and the subjacent interstitium; as well as among the periductal smooth muscle cells (SMCs) only in the buffalo bulls. Distinct GalTasebinding sites were found in the ductal epithelium only in the donkey. In conclusion the present findings exhibited a species-specific pattern of distribution for most of proteins under study, suggesting a variable functional significance of the DD in the different animal species.

\section{Keywords:}

Donkey, Ducts deferens, Immunohistochemistry, Water buffalo.

\section{Introduction}

The ductus deferens (DD) plays a key role in male fertility by providing an appropriate luminal environment for sperm before ejaculation (Hoffer, 1976; Silber, 1989; Carlin et al., 2002; Domeniconi et 
al., 2007; Orsi et al., 2009). Moreover, it was reported that DD has a complex epithelium (Setchell and Brooks, 2006), showing absorptive, synthetic and secretory activities in rodents (Chinoy, 1985; Manin et al., 1995; Orsi et al., 2009) and in humans (Hoffer, 1976). Thus, the DD is not only a passage for sperm transport (Setchell and Brooks, 2006), but also is an important organ contributing positively to the conservation of sperm structure, maturation, survival and viability (Chinoy, 1985; Silber, 1989; Carlin et al., 2002). Several studies (Clermont and Hermo, 1988; Breton et al., 1996; 1998; Brown and Breton, 2000) applied the rodents as a mammalian model to study the structure and the function of the DD.

Though previous studies showed that the DD from different mammals revealed common basic structure; represented by a folded mucosa, a threelayered muscularis and a serosa or an adventitia (Hoffer, 1976; Murakami et al., 1982; Paniagua et al., 1982; Lohiya et al., 1988; Khan et al., 2003), and some species-specific characteristics (Murakami et al., 1982; Chinoy, 1985; Khan et al., 2003), a great need for comparative studies did exist for promoting anatomical, histological and functional backgrounds about the DD in animals.

The immunomarkers "proteins" under study were chosen according to certain functional significance. Angiotensin converting enzyme (ACE) was selected to identify the structures related to the transport of electrolytes and water (O'Mahony et al., 2000). Galactosyltransferase (GalTase) was used to investigate the secretory activity. GalTase is a member of a functional family of intracellular, membrane-bounded enzymes that are responsible for the biosynthesis of carbohydrate fractions of

J. Vet. Anat. glycoproteins (GPs) (Hennet, 2002). Some GPs have a significant role in the male fertility. Both of a-smooth muscle actin (a-SMA) (Alkafafy et al., 2009), connexin 43 (Cx43) (Dufresne et al., 2003) and S100 (Heizmann et. al., 2002) were used to investigate the reciprocal activities between the ductal epithelial and the periductal non-epithelial structures of the DD. The a-SMA is a significant tool in studying differentiation of SMCs in normal and pathological conditions (Skalli et al., 1989). Connexins are members of a large family of integral membrane proteins (Thomas et al., 2002), which oligomerize to form intercellular channels known as gap junctions. lons, metabolites and second messengers diffuse directly from cell to another through these junctions (Segretain and Falk, 2004). The gap junctions facilitate the coordination of individual cells in an organ and provide a mechanism for regulating its biological function (Evans and Martin 2002). S100 is a multifunctional subfamily of $\mathrm{Ca} 2+-$ binding proteins that have a broad range of functions (Heizmann et. al., 2002) including motility, chemotaxis, neurite extension and secretion.

Therefore, the current study aimed to apply IHC to detect some of these interspecies differences. The immunolocalization of ACE, GalTase, $\alpha-S M A$, $\mathrm{Cx} 43$ and $\mathrm{S} 100$ was used to investigate the reciprocal activities between the ductal epithelial and the periductal nonepithelial structures of the DD in the donkey and water buffalo bulls that usually found in the Egyptian farming life.

\section{Materials and methods}

\section{Animals and tissues}

The DD specimens were obtained from five clinically healthy adult male don- 
keys (Equus asinus) and five Egyptian water buffalo bulls (Bubalus bubalis). Their ages ranged from 3 to 5 years. Specimens were taken directly after castration (of the donkeys) or slaughter (of the bulls).

\section{Chemicals and methods}

Specimens were fixed in Bouin's fluid and a mixture of methanol/glacial acetic acid (2:1). Bouin-fixed specimens were used for routine histological staining. For IHC specimens were fixed in Bouin's fluid (specimens used for detection of ACE, S-100, $\alpha-S M A$ and Cx-43) and in a methanol/glacial acetic acid mixture (specimens used for detection of GalTase). Tissue specimens were dehydrated in a graded series of ethanol, cleared in xylene, embedded in Paraplast wax ${ }^{1}$ and sectioned at $5 \mu \mathrm{m}$ thickness. Tissue sections were mounted on positively charged, coated slides ${ }^{2}$.

\section{General histological techniques}

Many conventional stains were carried out to investigate the general histological structure. These included Hematoxylin and Eosin, Masson and Goldner's trichrome stains, Alcian blue 8GX $(\mathrm{pH}$ 1.0 and $\mathrm{pH} 2.5$ ), Periodic acid-Schiff (PAS) reaction after McManus and Toluidine blue. All the staining techniques were performed according to Bancroft and Stevens (1990).

\section{Morphometric measurements}

The morphometric values of the different ductal components in both species were measured in transverse sections of the ductus deferens from all animals studied. Histomorphomertic measures were obtained in three different histological sections for each animal using

\footnotetext{
1 Sigma-Aldrich, St. Louis, MO, USA

${ }^{2}$ Menzel GmbH\&Co KG, Braunschweig, Germany
}

the eyepiece micrometer and $X 4$ and $\mathrm{X} 10$ objective lenses. Descriptive statistics are given as means \pm SD (standard deviation) ${ }^{3}$.

\section{Immunohistochemistry}

Dewaxed and rehydrated sections were subjected to inactivation of endogenous peroxidases by incubation in $1 \% \mathrm{H}_{2} \mathrm{O}_{2}$ for 15 minutes. Then after the sections were placed in $0.01 \mathrm{~mol} / \mathrm{L}$ citrate buffer $(\mathrm{pH} \mathrm{6)}$ and heated in microwave (700 watt) for 10 minutes for antigen retrieval. The sections were blocked by PBS containing $5 \%$ bovine serum albumin (BSA) for an hour, and then each section was incubated with its corresponding primary antibody (types, sources and dilutions of antibodies, and the duration of incubation are shown in Table 1 ). The sections were washed by PBS for 5 minutes 3 times and incubated with biotinylated secondry antibodies (types, sources and dilutions are shown in Table 1), for 30 minutes at room temperature. The sections were washed by PBS for 10 minutes. Then the secondary antibody was detected with Vectastain $A B C$ kit $^{4}$; firstly each section is covered with $100 \times$ dilution of $A$ \& B reagent in PBS $(1 \mu$ l reagent $A+$ $1 \mu \mathrm{l}$ reagent $\mathrm{B}+98 \mu \mathrm{l}$ PBS), then washed by PBS for 10 minutes 3 times and the colour was developed using $D A B^{5}$ reagent. Sections were counterstained with haematoxyline for 30 seconds, washed in water, dehydrated through graded ethanol, cleared in $x y-$ lene and mounted with DPX permanent mounting medi ${ }^{\mathrm{a} 6}$ and photographed by light microscopy

\section{Positive and negative controls}

\footnotetext{
${ }^{3}$ Microsoft_Excel 2003 program

${ }^{4}$ Vector Laboratories Inc.

${ }^{5}$ Sigma-Aldrich, St. Louis, MO, USA

${ }^{6}$ Sigma-Aldrich, St. Louis, MO, USA
} 
Immunohistochemical negative controls, where each primary or secondary antiserum or the $A B C$ reagent was omitted, gave no positive staining. Positive controls were used according to the instructions provided by the manufacturers of the primary antibodies. For assessment of the immunolabelling a semi-quantitative subjective scoring was performed by three independent observers.

\section{Results}

\section{Light microscopic observations}

The wall of the DD, both in the buffalo (Fig. 1a, 1b) and in the donkey (Fig. 1c, $1 d)$, was made up of three main layers: mucosa, muscularis and adventitia. The mucosa consisted of the epithelium and the underlying connective tissue lamina propria. The lining epithelium was high cuboidal in the donkey (Fig.1d), and tall columnar pseudostratified in the buffalo bull (Fig. 1b). The epithelium consisted of principal and basal cells, as well as a few migrating lymphocytes in both animal species. Together with the subjacent lamina propria, the epithelium was thrown up into numerous longitudinal mucosal folds. The number of folds ranged from 10 (in the buffalo) to 20 (in the donkey). The mucosal folds in the buffalo DD were relatively shorter and thicker (Fig. 1a, 1b), than those of the donkey (Fig. 1c, 1d). The tunica muscularis, in both animal species, consisted of three laminae: inner longitudinal, middle intermingled and outer longitudinal. While the inner layer was indistinct, both the middle and the outer layers were well-developed. The morphometric values of the different components of the DD in both species were summarized in Table 2 . In brief, with the exception of the epithelium height; that was higher in the buffalo $(64 \pm 10$ $\mu \mathrm{m}$ vs $21 \pm 4 \mu \mathrm{m}) \mathrm{DD}$; and muscularis' thickness; that was nearly two-fold thicker in donkey DD (1155 $\pm 240 \mathrm{vs}$ $712 \pm 155 \mu \mathrm{m})$, other morphometric parameters were higher in the $D D$ of the donkey than in the buffalo.

\section{Immunohistochemical observations}

The immunohistochemical findings of ACE, S-100, a-SMA, GalTase, and Cx43 in donkey and water buffalo bulls DD were summarized in Table 3 .

\section{Angiotensin Converting Enzyme (ACE)}

The basal cells of ductal epithelium of the buffalo exhibited a weak to moderate ACE-IR) (Fig. 2a). A marked immunostaining was evident in the stereocilia of the principal cells lining the DD of the donkey (Fig. 2b) but not of the buffalo (Fig. 2a). A strong reaction was distinct in the vascular endothelium in both species especially that of the subepithelial blood capillaries (Fig. 2a).

\section{S100}

Distinct S100 binding sites were localized in the nerve fibres in the lamina propria and the tunica muscularis; and in the subserosal nerves of the DD both in the buffalo bulls (Fig. 2c) and in the donkey (Fig. 2d). The positively reacting nerve network both in the subepithelial lamina propria and in the muscularis; showed further density in the male donkey (Fig. 2d) than in the buffalo bull. A weak S100-immunostining was recorded in the endothelium of the blood vessels in both species.

Alpha Smooth Muscle Actin (a-SMA) The IR for a-SMA exhibited a strong signal in both periductal and vascular SMCs. This pattern of reactivity was similar in both species (Fig. 3a, 3b).

Galactosyltransferase (GalTase) 
GalTase binding sites were evidently localized in the cytoplasm of the epithelium lining the DD of the donkey (Fig. $3 c)$. Moreover, the vascular endothelium exhibited a weak reaction. On the other hand the buffalo showed no GalTase-IR; either in the ductal epithelium or in the periductal structures.

\section{Connexin 43 (Cx43)}

Distinct dotty $\mathrm{Cx} 43$ binding sites were seen in the basal portions of the ductal epithelium and in the periductal muscle coat only in the buffalo (Fig. 3d).

\section{Discussion}

The information about the comparative histology of the mammalian DD exhibits a remarkable scarcity. Thus, the current study was carried out to provide a qualitative and quantitative comparative overview of the DD between the donkey and the buffalo. Similar to the case in other mammalian species (Hoffer, 1976; Murakami et al., 1982; Paniagua et al., 1982; Lohiya et al., 1988; Khan et al., 2003), the wall of the DD, both in donkey and buffalo, was made up of a mucosa, three concentric layers of SMCs and an adventitia. The epithelium, together with the subjacent lamina propria, was thrown up into numerous longitudinal folds. The number of folds ranged from 10 (in the buffalo) to 20 (in the donkey). The higher numerical density and heights of the mucosal folds in the donkey DD may confer a labyrintheal appearance to its lumen that may be of value in slowing down of the seminal stream and enhancement of the absorptive activities. Furthermore, the mucosal lining was found to be high cuboidal ( $21 \pm 4 \mu \mathrm{m}$, in the donkey) to tall columnar $(64 \pm 10 \mu \mathrm{m}$, in the buffalo) pseudostratified epithelium with stereocilia. In the meantime, Khan et al.
(2003) showed that the DD of buffalo and goat characteristically possess four mucosal folds and that the lining epithelium was low columnar pseudostratified, this discrepancy might be due to age (Macmillan and Hafs, 1969; AbdelRaouf and Hassan, 1981) or regional variations (Chinoy, 1985).

The donkey and buffalo bull DD had indistinct inner longitudinal and welldeveloped middle layers, like other mammals (Paniagua et al., 1982; Lohiya et al., 1988; Khan et al., 2003). The SMCs of the middle layer, in both species, showed an intermingled (circular, longitudinal and oblique) pattern of orientation (Wrobel, 1998). Yet, the circular profile predominates in buffalo DD. The outer longitudinal layer was well distinct and consisted of coarse bundles of SMCs particularly in the donkey. It was also noticeable that the muscularis of the donkey DD was nearly two folds thicker than that in the buffalo DD. Taken together the tunica muscularis displayed not only qualitative but also quantitative differences in the two species under study.

Immunohistochemical localization of S100 protein in the donkey and the buffalo DD, especially in the nerve fibres in the lamina propria, tunica muscularis and subserosa of the DD agrees with Slater et al., (2000) who recorded that $\mathrm{S} 100$ can be used as an axonal marker; and indicate the significance of $\mathrm{S} 100$ proteins in the vasal autonomic nerves which control the male reproductive function. The strong density of S100-IR in the nerve network both in the subepithelial lamina propria and in the muscularis, in accordance with a previous work (Mirabella et al., 2003), showed the presence of a very dense nerve network in both layers. Additionally, the dense nerve network distributed throughout the periductal 
muscle coat reflected that the ductal motility is fully under the control of the autonomic nervous system (Dixon et al., 1998; Mirabella et al., 2003). Also, the higher density of the subepithelial nerve network in the donkey, and the broader propria $(140 \pm 10 \mu \mathrm{m}$ vs. $36 \pm 5$ $\mu \mathrm{m})$ might reflect the paramount implication of the autonomic nerves in the regulation of the DD function in the donkey. It is obvious that the subepithelial nerves of the DD are assumed to have a secreto-motor function (Dixon et al., 1998; Jen et al., 1999; Mirabella et al., 2003).

The marked GalTase-immuno-staining in the cytoplasm of the principal and basal cells lining the DD of the donkey but not of the buffalo may reveal some species-specific peculiarities. Although previous studies on the epididymis of both corresponding species (Alkafafy, 2009; Alkafafy et al., 2009) displayed positive GalTase-IR, the distribution pattern showed interspecies differences. Unlike the buffalo, the cauda epididymidis of the donkey expressed a strong IR suggesting that the distal segments of the male excurrent ducts, including the DD, may present some secretory activities (Manin et al., 1995; Orsi et al., 2009). Contrarily, in human; the GalTase activity was high in the intermediate caput and proximal corpus regions, but maintained low in cauda epididymidis and the vas deferens (Ross et al., 1993). GalTase plays a role in gamete interaction (Larson and Miller, 1997) and serves as a generalized gamete receptor during initial sperm-egg binding in mammals (Fayrer-Hosken et al., 1991). Accordingly, the absence of GalTase expression in buffalo bull DD combined with high testicular sperm output might provide species-specific mean to reduce the spermoocyte encounter and block of polyspermy.

J. Vet. Anat.
Although a strong ACE-IR was evident in the stereocilia of the principal cells lining the DD of the donkey, those of the buffalo bull DD was devoid from ACE signals that is might be due to higher secretion of an ACE inhibiting substance (Hohlbru-gger et al, 1983) from bull epididymal epithelium. Nevertheless, the stereocilia of the epithelium lining the donkey cauda epididymidis (Alkafafy, 2009), the bovine caput epididymidis (Alkafafy and Sinowatz, 2009), the rabbit DD (Berg et al., 1986) and the human DD (Vivet et al., 1987; Pauls et al., 2003) displayed a strong ACE-IR. The basal cells of the DD epithelium of the buffalo displayed a moderate ACE-IR. Similar findings could be found in the epididymal basal cells in rabbits (Berg et al., 1986) but not in humans (Vivet et al., 1987). It is evident that this reaction was mostly in proximity with the strongly reacting subepithelial blood capillaries. It is worth noting that ACE is an ectoenzyme, which is synthesized and secreted by the epithelial cells of the epididymis and the DD (Berg et al., 1986). ACE stimulates angiogenesis in vivo (Fernandez et al, 1985) and acts as a growth factor (Naftilan et al., 1989) in cell culture systems; thus it may keep maintenance of the blood supply of the excurrent duct system.

Functionally, ACE is known to be crucial for male fertility in animal models (Pauls et al, 2003); it converts angiotensin-I, locally produced by male reproductive tract; into angiotensin-II (O'Mahony et al., 2000). Angiotensin potentiates electrical stimulated contraction and exerts a direct contractile effect on the muscle of DD (Sum and Cheung, 1995). Moreover, it can stimulate sperm motility, the acrosome reaction and binding to the zona pellucida and is also concerned with regulation of electrolyte and fluid transport (O'Maho- 
ny et al., 2000). Our findings were also supported by recent studies indicated that the transepithelial movement of water and electrolytes takes place via protein water channels (aquaporins) immunolocalized in the apical surface of the excurrent ducts (Domeniconi et al., 2007; Skowronski et al., 2009).

The current results showed that the cytoplasm of the periductal SMCs presented a marked $\alpha-S M A-I R$. This work is a contnuation of earlier findings reported the presence of $\alpha-S M A$ in the epididymal duct of the donkey (Alkafafy, 2009) and the buffalo bull (Alkafafy et al, 2009) and suggesting the maintenance of its function in DD likewise in the epididymis. Mewe et al. (2006) showed that the muscular autorhythmicity of the epididymal duct results from $\alpha$-SMA-positive contra-ctile cells, in response to epithelium-derived excitatory prostaglandins. This autorhythmicity propulses spermatozoa through the epididymal duct, thereby ensuring sperm maturation. Similar mechanism has been proved on SMCs of the DD (Ruan et al., 2008).

In addition to the endocrine and the paracrine control, gap junctions and their constitutive proteins, connexins, are essential for the control of male fertility. Connexin 43 (Cx43) is the predominant testicular gap-junction protein (Sridharan et al, 2007). Additionally in the present study, a strong punctuate, dotty Cx43-IR was found in the basal portions of the ductal epithelium and throughout the periductal muscle coat only in the buffalo. These findings were supported by the detection of nexuses among SMCs in a previous work on the DD (Cobb and Bennett, 1969). Moreover, the epithelial Cx43-binding sites, reported in the buffalo DD, go in line with previous studies on the buffalo (Alkafafy et al., 2009), the stallion (Hejmej et al.,
2007) and the rat (Dufresne et al., 2003) epididymides. On the other hand, and in accord with Alkafafy (2009), neither the epithelial nor the muscular Cx43-binding sites could be seen in the donkey DD. The immunohistochemical findings in the present work assume that the lack of Cx43-IR, in the donkey, may be compensated by the S100immunoreactive dense network of nerves both in the lamina propria and tunica muscularis. Occurrence of gap junctions (Cx-binding sites) might reveal the reciprocal relationships between the ductal epithelium and the periductal components, necessary for regu-lation of the different functions (Segretain and Falk, 2004; Palani et al., 2006; Hejmej et al., 2007) of the duct.

In conclusion, the immunohistochemical findings in the present work displayed a species-specific, distribution pattern for most of proteins under study, suggesting a variable functional significance of the DD in the two species. In accord with previous studies on humans and rodents our findings, particularly of the donkey, assume that the DD possess variable degrees of absorptive, synthetic and secretory activities. Therefore, the current results conclude that DD epithelia may play an active role in male fertility. Yet, this concept could not be generalized for all animal species, since some interspecies differences did exist. Thus, our study just highlighted the issue and further, extensive, comparative studies on different domestic mammals are highly recommended.

\section{Acknowledgements}

We would like to acknowledge the help of Professor Fred Sinowatz; Institute of Veterinary Anatomy II, LMU, Munich, Germany; for providing the primary antibodies used in this study. 


\section{References}

Abdel-Raouf M, Hassan AH. (1981):

The postnatal development of the ductus deferens and ampulla in bulls. Z. Mikrosk. Anat. Forsch. 95: 785-796.

Alkafafy M. (2009): Some immunohistochemical studies on the epididymal duct in th donkey (Equus asinus). J. Vet. Anat. 2(2): 1-23.

Alkafafy M, Elnasharty M, SayedAhmed A, Abdrabou M. (2009): Immunohistochemical studies of the epididymal duct in Egyptian water buffalo (Bubalus bubalis). Acta. Histochem. (in press).

Alkafafy M, Sinowatz F. (2009): Immunolocalization of angiotensin converting enzyme in foetal and adult bovine epididymis. Minufiya Vet. J 6(1):13-23.

Bancroft JD, Stevens A. (1990):

Theory and Practice of Histological Techniques, 3rd ed. Churchill Livingstone, London, Torento.

Berg T, Sulner J, Lai CY, Soffer RL. (1986): Immunohistochemical localization of two angiotensinI-converting isoenzymes in the reproductive tract of the male rabbit. J. Histochem. Cytochem. 34: 753-760.

Breton S, Hammar K, Smith PJS, and Brown D. (1998): Proton secretion in the male reproductive tract: involvement of $\mathrm{Cl}^{-}$independent $\mathrm{HCO}^{-}$transport. Am. J. Physiol. Cell Physiol. 275: C1134-1142.

Breton S, Smith PJ, Lui B, and Brown D. (1996): Acidification of the male reproductive tract by a proton pumping $\left(\mathrm{H}^{+}\right)$ATPase. Nat. Med. 2: 470-472.
Brown D, Breton S. (2000): H (+) VATPase-dependent luminal acidification in the kidney collecting duct and the epididymis/vas deferens: vesicle recycling and transcytotic pathways. J. Exp. Biol. 203: 137-145.

Carlin RW, Quesnell RR, Zheng L, Mitchell KE, Schultz BD. (2002): Functional and molecular evidence for $\mathrm{Na}(+)-\mathrm{HCO}$ cotransporter in porcine vas deferens epithelia. Am. J. Physiol. Cell Physiol. 283: C1033-1044.

Chinoy NJ. (1985): Structure and physiology of mammalian vas deferens in relation to fertility regulation. J. Biosci. 7 215221.

Clermont Y, Hermo L. (1988): Structure of the complex basement membrane underlying the epithelium of the vas deferens in the rat. Anat. Rec. 221: 482493.

Cobb JL, Bennett T. (1969): A Study of nexuses in visceral smooth muscle. J. Cell Biol. 41: 287297.

Dixon JS, Jen PY, Gosling JA.

(1998): Structure and autonomic innervation of the human vas deferens: a review. Microsc. Res. Tech. 42: 423-432.

Domeniconi RF, Orsi AM, Justulin LA Jr, Beu CC, Felisbino SL (2007): Aquaporin 9 (AQP9) localization in the adult dog testis excurrent ducts by immunohistochemistry. Anat. Rec. 290: 1519-1525.

Dufresne J, Finnson KW, Gregory

M, Cyr DG. (2003): Expression of multiple connexins in the rat epididymis indicates a complex regulation of gap junctional communication. Am. J. Physiol. Cell Physiol. 284: C33-43.

Evans WH, Martin PE. (2002): Gap 
junctions: structure and function (review). Mol. Membr. Biol. 19: 121-136.

Fayrer-Hosken RA, Caudle AB, Shur BD. (1991): Galactosyltransferase activity is restricted to the plasma membranes of equine and bovine sperm. Mol. Reprod. Dev. 28: 74-78.

Fernandez LA, Twickler J, Mead A.

(1985): Neovascularization produced by angiotensin II. J Lab Clin Med. 105: 141-145.

Heizmann CW, Fritz G, Schafer

BW. (2002): S100 proteins: structure, functions, and pathology. Front. Biosci. 7: d13561368.

Hejmej A, Kotula-Balak M, Sadows

ka J, Bilińska B. (2007): Expression of connexin 43 protein in testes, epididymides and prostates of stallions. Equine. Vet. J. 39: 122-127.

Hennet T. (2002): The galactosyltransferase family. Cell Mol. Life Sci. 59: 1081-1095.

Hoffer AP. (1976): The Ultrastructure of the Ductus Deferens in Man. Biol. Reprod. 14: 425443.

Hohlbrugger G, Dahlheim H (1983):

The effect of age, mating and vasoligature on angiotensin I converting enzyme in rat testis and epididymis. Adv. Exp. Med. Biol. B 156: 845-853.

Jen PYP, Dixon JS, Gosling JA. (1999): Colocalisation of neuropeptides, nitric oxide synthase and immunomarkers for catecholamines in nerve fibres of the adult human vas deferens. J. Anat. 195: 481-489.

Khan, AA, Zaidi, MT; Faruqi, NA. (2003): Ductus Deferens- a Comparative Histology in Mammals. J. Anat. Soc. India. 52: 163-165.
Larson JL, Miller DJ. (1997): Sperm

from a variety of mammalian species express beta1, 4galactosyltransferase on their surface. Biol. Reprod. 57: 442453.

Lohiya NK, Sharma RS, Ansari AS, Anand Kumar TC. (1988): Structure of rete testis, vas efferens, epididymis and vas deferens of langur monkey (Presbytis entellus entellus Dufresne). Acta. Eur. Fertil. 19: 167-173.

Macmillan KL, Hafs HD. (1969):

Reproductive tract of Holstein bulls from birth through puberty. J. Anim. Sci. 28: 233-239.

Manin M., Lecher P, Martinez A, Tournadre S, Jean C. (1995): Exportation of Mouse Vas Deferens Protein, a Protein without a Signal Peptide, from Mouse Vas Deferens Epithelium: A Model of Apocrine Secretion. Biol. Reprod. 52: 50-62.

Mewe M, Bauer CK, Schwarz JR,

Middendorff R. (2006): Mechanisms regulating spontaneous contractions in the bovine epididymal duct. Biol. Reprod. 75: 651-659.

Mirabella N, Squillacioti C, Varricchio E, Genovese A, Paino G. (2003): Innervation of vas deferens and accessory male genital glands in the water buffalo (Bubalus bubalis). Neurochemical characteristics and relationships to the reproductive activity. Theriogenology 59: 1999-2016.

Murakami M, Sugita A, Hamasaki M. (1982): Scanning electron microscopic observations of the vas deferens in man and monkey with special reference to spermiophagy in its ampullary 
region.Scan. Electron. Microsc. (Pt 3):1333-1339.

Naftilan AJ, Pratt RE, Dazu VJ. (1989): Induction of plateletderived growth factor A-chain and c-myc gene expressions by angiotensin II in cultured rat vascular smooth muscle cells. J. Clin Invest, 83: 1419-1424.

O'Mahony OA, Djahanbahkch O, Mahmood T, Puddefoot JR, Vinson GP. (2000): Angiotensin II in human seminal fluid. Hum. Reprod. 15: 1345-1349.

Orsi AM, Simoes K, Domeniconi

RF, Da Cruz C, Machado MRF, Filho JG. (2009): Vas deferens surface epithelium of Agouti paca: fine structural features. Int. J. Morphol. 27: 89-96.

Palani D, Ghildyal P, Manchanda R. (2006): Effects of carbenoxolone on syncytial electrical properties and junction potentials of guinea-pig vas deferens. Naunyn. Schm-iedebergs Arch. Pharmacol. 374: 207-214.

Paniagua R, Regadera J, Nistal M, Abaurrea MA. (1982): Histological, histochemical and ultrastructural variations along the length of the human vas deferens before and after puberty. Acta. Anat. (Basel) 111:190203

Pauls K, Metzger R, Steger K, Klonisch T, Danilov S, Franke FE. (2003): Isoforms of angiotensin I-converting enzyme in the development and differentiation of human testis and epididymis. Andrologia. 35: 32-43.

Ross P, Vigneault N, Provencher S, Potier M, Roberts KD. (1993): Partial characterization of galactosyltransferase in human seminal plasma and its distribution in the human epididymis. J. Reprod. Fertil. 98: 129-137.
Ruan YC, Wang Z, Du JY, Zuo WL, Guo JH, Zhang J. et al. (2008): Regulation of smooth muscle contractility by the epithelium in rat vas deferens: role of ATP. induced release of PGE2. J. Physiol. 586: 4843-4857.

Segretain D, Falk MM. (2004): Regulation of connexin biosynthesis, assembly, gap junction formation, and removal. Biochim. Biophys. Acta. 1662: 321.

Setchell BP, Brooks DE. (2006):

Anatomy, vasculature, innervation, and fluids of the male reproductive tract. Chapter 17 , volume 1. In: Knobil E and Neill JD (eds), The Physiology of Reproduction; $3^{\text {rd }}$ ed. Raven press, New York. pp. 770-825.

Silber, SJ. (1989): Results of microsurgical vasoepididymostomy: Role of epididymis in sperm maturation. Human. Reprod. 4: 298-303.

Skalli O, Pelte MF, Peclet MC, Gabbiani G, Gugliotta P, Bussolati G. et al. (1989): Alphasmooth muscle actin, a differentiation marker of smooth muscle cells, is present in microfilamentous bundles of pericytes. J. Histochem. Cytochem. 37: $315-321$.

Skowronski MT, Leska A, Robak A, Nielsen S. (2009): Immunolocalization of aquaporin-1, -5 , and 7 in the avian testis and vas deferens. J. Histochem. Cytochem. 57: 915-922.

Slater M, Barden JA, Murphy CR. (2000): Tyrosine kinase A, autonomic and transmitter receptors, but not innervation, are upregulated in the aging rat prostate. Acta. Histochem. 102: 427-438.

Sridharan S, Brehm R, Bergmann 
M, Cooke PS. (2007): Role of Connexin 43 in Sertoli Cells of Testis. Ann N Y Acad. Sci. 1120: 131-143.

Sum CS, Cheung WT. (1995): Characterization of contractile response to angiotensin in epididymal rat vas deferens. Pharmacology. 51: 105-111.

Thomas MA, Huang S, Cokoja A,

Riccio O, Staub O, Suter S. et al. (2002): Interaction of connexins with protein partners in the control of channel turnover and gating. Biol. Cell. 94: 445456.
Vivet F, Callard P, Gamoudi A.

(1987): Immunolocalization of angiotensin 1 converting enzyme in the human male genital tract by the avidin-biotincomplex method. Histochemistry. 86: 499-502.

Wrobel, K-H. (1998): Male Repro-

Ductive System. Chapter 12, In: Dellmann HD and Eurell J, (eds), Textbook of Veterinary Histology., 5th ed., Williams and Wilkins. pp. 226-246.

Table 1: Identity, sources, and working dilutions of primary and secondary antibodies.

\begin{tabular}{|c|c|c|c|c|c|c|c|}
\hline \multicolumn{5}{|c|}{ Primary antibodies } & \multicolumn{3}{|c|}{ Secondary antibodies } \\
\hline $\begin{array}{l}\text { Agains } \\
t\end{array}$ & Origin & Source & $\begin{array}{c}\text { Dilu- } \\
\text { tion }\end{array}$ & $\begin{array}{c}\text { Incubation } \\
\text { time }\end{array}$ & Type & Source & $\begin{array}{c}\text { Dilu- } \\
\text { tion }\end{array}$ \\
\hline ACE & Chicken & $\begin{array}{l}\text { Institute of } \\
\text { Vet. Anat. } \\
\text { II, LMU } \\
\text { Munich }\end{array}$ & $1: 500$ & $\begin{array}{l}\text { Overnight } \\
\text { at } 4^{\circ} \mathrm{C}\end{array}$ & $\begin{array}{l}\text { Biotiny- } \\
\text { lated rabbit } \\
\text { antichicken } \\
\text { lgG }\end{array}$ & $\begin{array}{l}\text { Rock- } \\
\text { land, } \\
\text { USA }\end{array}$ & $1: 400$ \\
\hline $\begin{array}{l}\text { Gal- } \\
\text { Tase }\end{array}$ & Chicken & $\begin{array}{l}\text { Institute of } \\
\text { Vet. Anat. } \\
\text { II, LMU } \\
\text { Munich }\end{array}$ & $1: 500$ & $\begin{array}{l}\text { Overnight } \\
\text { at } 4^{\circ} \mathrm{C}\end{array}$ & $\begin{array}{l}\text { Biotiny- } \\
\text { lated rabbit } \\
\text { antichicken } \\
\text { IgG }\end{array}$ & $\begin{array}{l}\text { Rock- } \\
\text { land, } \\
\text { USA }\end{array}$ & $1: 400$ \\
\hline S100 & Rabbit & $\begin{array}{l}\text { Dako, } \\
\text { Hamburg }\end{array}$ & $1: 400$ & $\begin{array}{l}1 / 2 \mathrm{hr} \text { at } \\
\text { room } \\
\text { tempera- } \\
\text { ture }\end{array}$ & $\begin{array}{l}\text { Biotiny- } \\
\text { lated pig } \\
\text { anti-rabbit } \\
\text { lgG }\end{array}$ & $\begin{array}{l}\text { Dako, } \\
\text { Hamburg }\end{array}$ & $1: 300$ \\
\hline aSMA & Mouse & $\begin{array}{l}\text { Dako, } \\
\text { Hamburg }\end{array}$ & $1: 200$ & $\begin{array}{l}1 \mathrm{hr} \text { at } \\
\text { room } \\
\text { tempera- } \\
\text { ture }\end{array}$ & $\begin{array}{l}\text { Biotiny- } \\
\text { lated rabbit } \\
\text { antimouse } \\
\text { lgG }\end{array}$ & $\begin{array}{l}\text { Dako, } \\
\text { Hamburg }\end{array}$ & $1: 300$ \\
\hline Cx 43 & Mouse & $\begin{array}{l}\text { BD Bios- } \\
\text { cience, } \\
\text { Heidelberg }\end{array}$ & $1: 200$ & $\begin{array}{l}\text { Overnight } \\
\text { at } 4^{\circ} \mathrm{C}\end{array}$ & $\begin{array}{l}\text { Biotiny- } \\
\text { lated rabbit } \\
\text { antimouse } \\
\text { lgG }\end{array}$ & $\begin{array}{l}\text { Dako, } \\
\text { Hamburg }\end{array}$ & $1: 300$ \\
\hline
\end{tabular}


Table 2: Morphometric values of the different vasal parameters expressed as mean $(\mu \mathrm{m}) \pm$ standard deviation.

\begin{tabular}{|l|c|c|}
\hline \multicolumn{1}{|c|}{ Parameter } & Donkey & Buffalo \\
\hline Epithelium height & $21 \pm 4$ & $64 \pm 10$ \\
\hline Mucosal fold height & $278 \pm 49$ & $127 \pm 32$ \\
\hline Internal diameter & $800 \pm 34$ & $530 \pm 65$ \\
\hline Lamina propria & $140 \pm 10$ & $36 \pm 5$ \\
\hline Muscularis & $1155 \pm 240$ & $712 \pm 155$ \\
\hline Adventitia & $370 \pm 65$ & $303 \pm 42$ \\
\hline External diameter & $4110 \pm 155$ & $2610 \pm 143$ \\
\hline
\end{tabular}

*: The diameter extends between the basal laminae of a cross section of the DD.

**: The diameter extends between the outer adventitial borders of a cross section of the DD.

Table 3: Immunolocalization of different proteins in the ductus deferens of the donkey and the buffalo bull.

\begin{tabular}{|c|c|c|c|c|c|c|c|c|c|c|c|c|}
\hline \multirow[t]{3}{*}{ Protein } & \multicolumn{6}{|c|}{ Donkey } & \multicolumn{6}{|c|}{ Buffalo } \\
\hline & \multicolumn{3}{|c|}{$\begin{array}{l}\text { Ductal Epithe- } \\
\text { lium }\end{array}$} & \multicolumn{3}{|c|}{$\begin{array}{l}\text { Periductal } \\
\text { Components }\end{array}$} & \multicolumn{3}{|c|}{$\begin{array}{l}\text { Ductal Epithe- } \\
\text { lium }\end{array}$} & \multicolumn{3}{|c|}{$\begin{array}{l}\text { Periductal } \\
\text { Components }\end{array}$} \\
\hline & BC & PC & IEL & PMC & BV & $\mathbf{N}$ & BC & PC & IEL & PMC & BV & $\mathbf{N}$ \\
\hline $\mathbf{S 1 0 0}$ & - & - & - & - & + & +++ & - & - & - & - & + & +++ \\
\hline ACE & - & +++ & - & - & ++ & - & $+/++$ & - & - & - & +++ & - \\
\hline$\alpha-S M A$ & - & - & - & +++ & +++ & - & - & - & - & +++ & +++ & - \\
\hline Cx43 & - & - & - & - & - & - & +++ & +++ & - & +++ & - & - \\
\hline GalTase & + & +++ & - & - & + & - & - & - & - & - & - & - \\
\hline
\end{tabular}

Immunostaining for $\mathrm{Cx} 43$ was confined to the base of the ductal epithelium. Basal cell (BC); principal cell (PC); intraepithelial lymphocyte (IEL); periductal muscle coat (PMC); blood vessel (BV) and nerve $(\mathrm{N})$. Negative $(-)$; weak $(+)$; moderate $(++)$; weak to moderate $(+/++)$ and strong $(+++)$ reaction. 

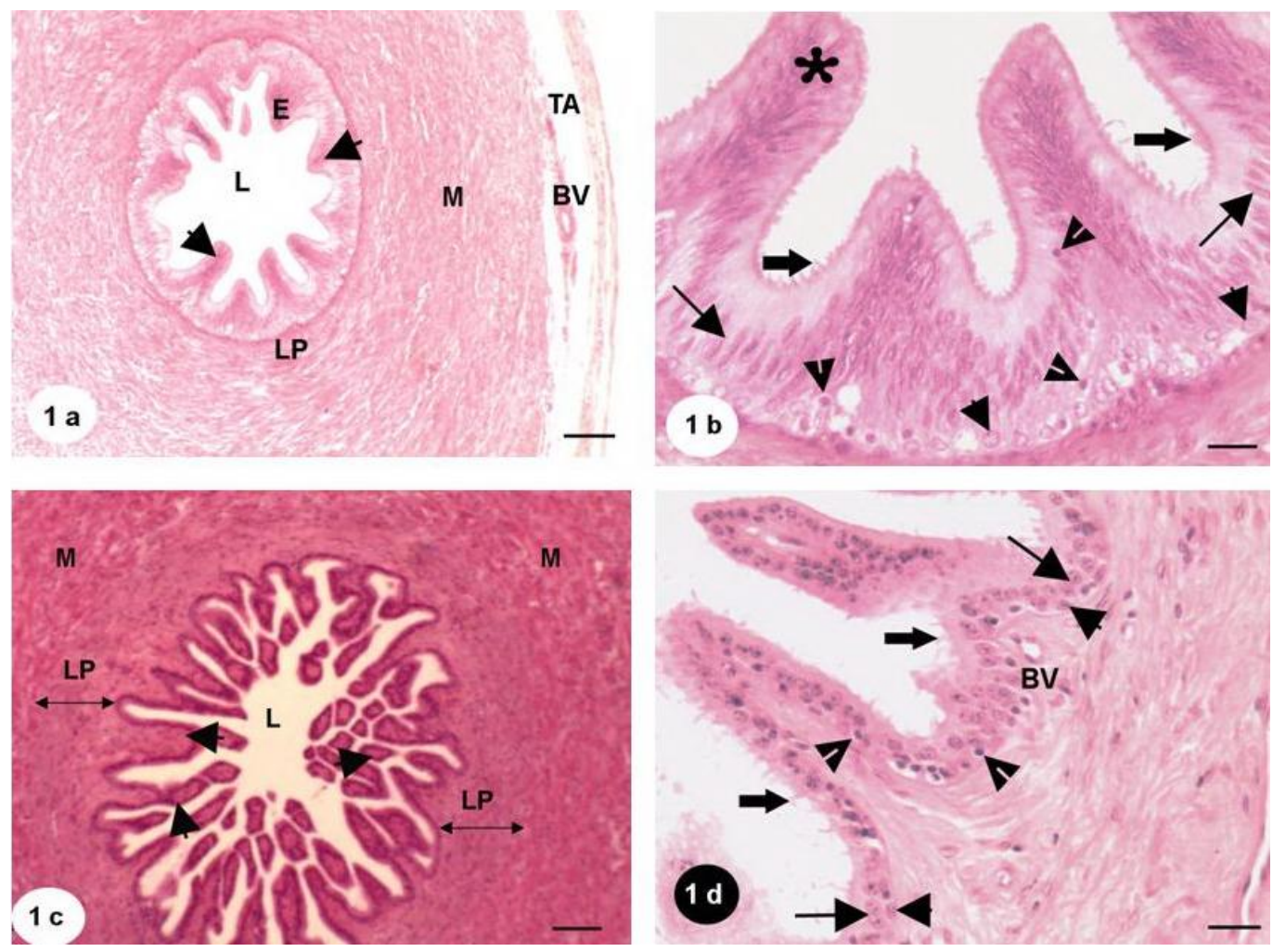

Fig (1)

(a) H\&E-stained ductus deferens of the buffalo bull: ductal epithelium (E); ductal lumen (L); lamina propria (LP); muscularis (M); tunica adventitia (TA); blood vessel (BV); mucosal folds (arrowheads).

(b) A higher magnification of H\&E-stained ductus deferens of the buffalo bull: basal cells (arrowheads); principal cells (thin-tailed arrows); stereocilia (thick-tailed arrows); intraepithelial lymphocytes (notched arrowheads); mucosal folds (asterisks).

(c) H\&E-stained ductus deferens of the donkey: extensively folded epithelium displaying high mucosal folds (arrowheads); lumen (L); lamina propria (LP); muscularis (M).

(d) A higher magnification of H\&E-stained ductus deferens of the donkey: basal cells (arrowheads); principal cells (thin-tailed arrows); stereocilia (thick-tailed arrows); intraepithelial lympho-

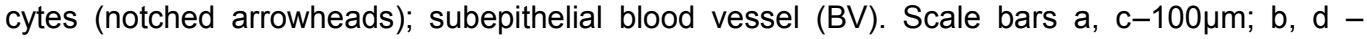
$25 \mu \mathrm{m}$. 

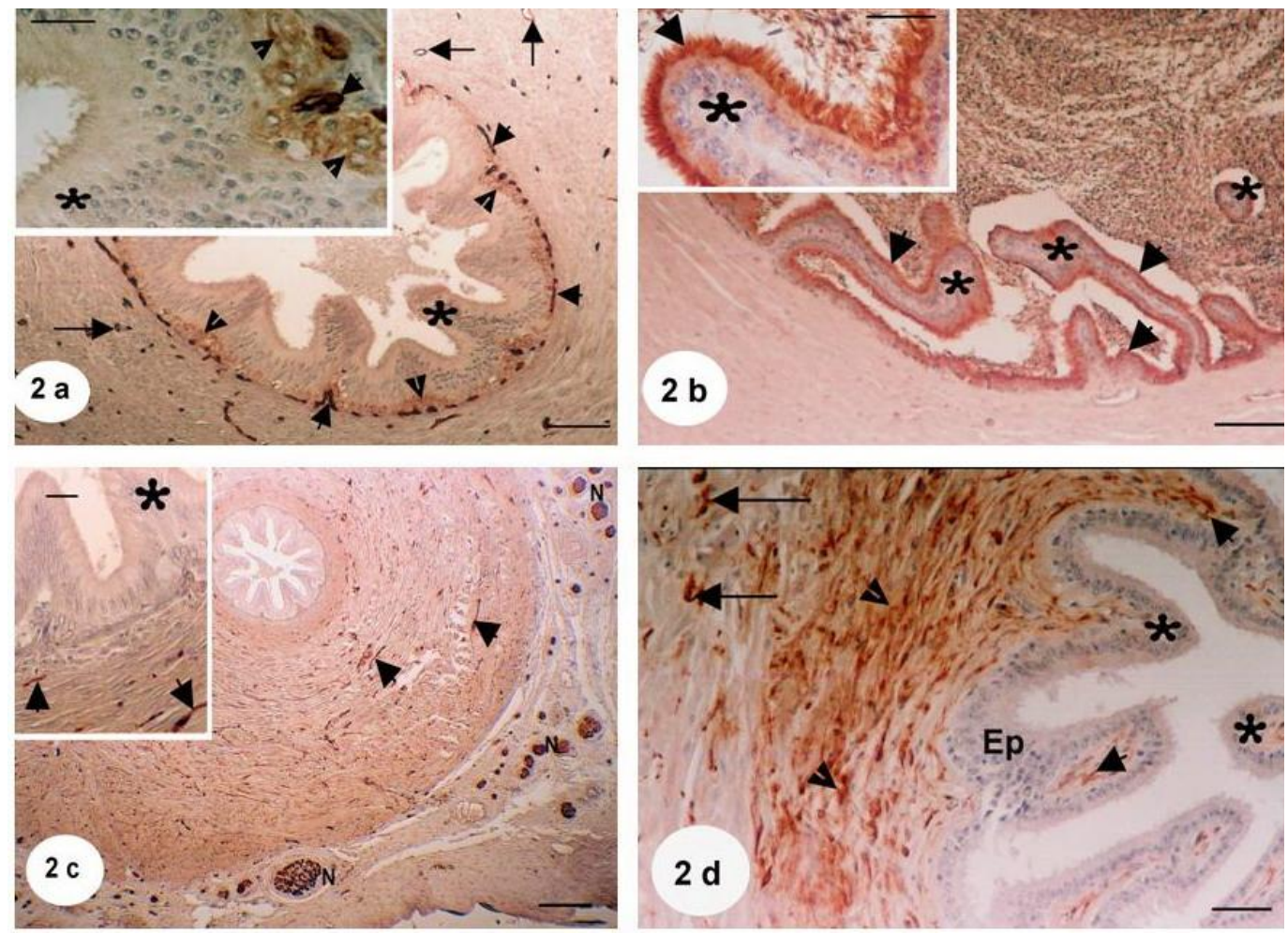

Fig (2)

(a) ACE-binding sites in the ductus deferens of the buffalo bull: basal cells (notched arrowheads) show moderate reaction; blood vessels (arrows) and subepithelial blood capillaries (arrowheads) show strong reactivity; mucosal folds (asterisks).

(b) ACE-binding sites in the ductus deferens of the donkey: strong reaction is evident in stereocilia (arrowheads); mucosal folds (asterisks).

(c) Distribution of S100-binding sites in the ductus deferens of the buffalo bull: strong reaction in the nerve fibers (arrowheads) of propria and muscularis and in the nerves ( $N$ ) in adventitia; mucosal folds (asterisks).

(d) Distribution of S100-binding sites in the ductus deferens of the donkey: negative reaction in the epithelium (Ep); strong reaction in the dense network of nerve fibers in lamina propria (notched arrowheads), in the connective tissue core (arrowheads) of mucosal folds (asterisks) and

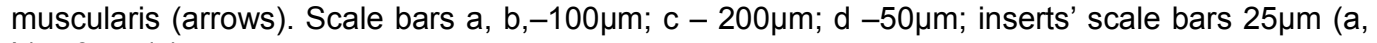
b); $50 \mu \mathrm{m}$ (c). 

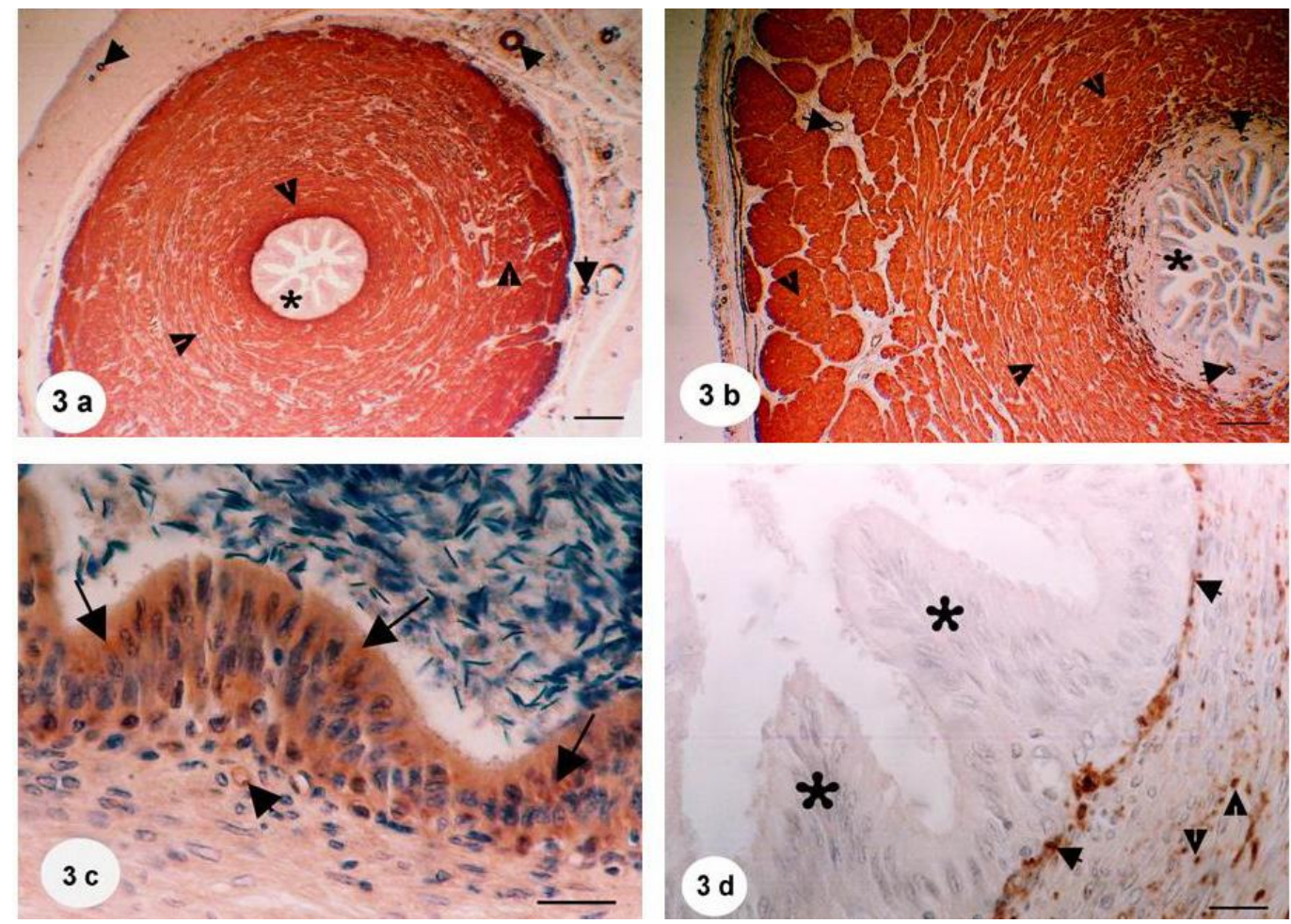

Fig (3)

(a) Distribution of a-SMA binding sites in the ductus deferens of the buffalo bull: strong reaction in periductal (notched arrowheads) and vascular (arrowheads) smooth muscle cells; mucosal folds (asterisks).

(b) Distribution of a-SMA binding sites in the ductus deferens of the donkey: strong reaction in periductal (notched arrowheads) and vascular (arrowheads) smooth muscle cells; mucosal folds (asterisks).

(c) Distribution of GalTase-binding sites in the ductus deferens of the donkey: the ductal epithelium displays moderate to strong reaction in the apical cytoplasm (arrows); weak reaction in a blood vessel (arrowhead).

(d) Distribution of Cx43-binding sites in the ductus deferens of the buffalo bull: distinct dotty reaction found amid smooth muscle cells (notched arrowheads) and between the basal portions (arrowheads) of the ductal epithelium and the lamina propria; mucosal folds (asterisks). Scale bars a, b $-200 \mu m ; c, d-25 \mu m$. 